\title{
Valuation of Environmental Impact Due to Material Construction Mining, Gowa, South Sulawesi
}

\author{
Andi Arjan ${ }^{\mathrm{a}}$, Arikah Nurhusna Afifah ${ }^{\mathrm{b}}$, Yubelium Andrew Patila ${ }^{\mathrm{c}}$, Aryanti Virtanti Anas ${ }^{\mathrm{d}}$ \\ ${ }^{a}$ Department of Mining Engineering, Faculty of Engineering, Hasanuddin University. Email: andiarjanpm@gmail.com \\ bDepartment of Environmental Engineering, Faculty of Engineering, Hasanuddin University. Email: arikahna@ gmail.com \\ cDepartment of Mining Engineering, Faculty of Engineering, Hasanuddin University. Email: yubelpatila@mail.com \\ ${ }^{\mathrm{d}}$ Department of Mining Engineering, Faculty of Engineering, Hasanuddin University. Email: virtanti@gmail.com
}

\begin{abstract}
Sand, river stone, soil excavation, sandstone, and broken stone are the types of construction materials mining in Gowa Regency and many are found in the Jeneberang River. The Jeneberang River is one of the main rivers in South Sulawesi. However, construction materials mining carried out around the Jeneberang River has a negative impact on the surrounding environment. Those negative impacts are erosion, road damage, noise, air pollution, and a decrease in water quality. This research was conducted in Gowa Regency. The method used is the Contingent valuation method (CVM). CVM consists of the desire to pay (Willingness to Pay or WTP) and the desire to accept (Willingness to Accept or WTA. While the social aspect conducts interviews with questionnaire questions to respondents to find out opinions about the surrounding environment. From this study, it is known that WTP and WTA data are inversely proportional. The greater the compensation to be paid, the more societies who want to receive and the fewer companies paid for the compensation.
\end{abstract}

Keywords: Environmental impact, construction materials, WTA, WTP

\section{Introduction}

\subsection{Background}

According to Law No.23 of 1997 concerning Environmental Management, the definition of environmental damage is an action that results in direct or indirect changes to its physical and/or biological properties which causes the environment to no longer function in supporting sustainable development. Environmental problems from sand mining activities require proper handling so that environmental damage having been occurred does not get worse. This is also important for the sustainability of construction material mining activities itself. In fact, changes in the face of the earth caused by open mining can affect environmental balance [1].

The Jeneberang River is one of the major and important rivers in the South Sulawesi Province. This is due to the flow of the Jeneberang River through Gowa Regency, Takalar District and Makassar City [2]. The Jeneberang River is a watershed that flows its water to Makassar City towards the lower reaches of the Makassar Strait and originates from the eastern part of Mount

${ }^{\star}$ Corresponding author. Tel.: +62-851-4603-5438 Jalan Poros Malino km. 6 Bontomarannu, Gowa South Sulawesi, Indonesia 92171
Bawakaraeng (2,833 masl). In the flow area of Jeneberang River, there are two main water catchment areas, such as in the city of Bili-bili and Jenelata. Raw water taken from the Jeneberang River is located seven $\mathrm{km}$ south of the city, pumped through a closed channel to the Ratulangi Installation. The river is also a supplier of raw water for the supply of clean water in Makassar City and Sungguminasa District, Gowa Regency [2].

Construction material mining has been operating for more than 19 years in the Jeneberang River and based on data from the Department of Energy and Mineral Resources of South Sulawesi Province, there are 35 construction materials mining in Gowa Regency, which cause environmental impacts. Environmental impacts resulting from mining activities can be felt by the local community. The pollution impact occurred is river erosion, a decrease in water quality, noise, air pollution, and road damage. The environmental impact is caused by the lack of attention of mining companies, so that it is necessary to have an environmental valuation and serve as the cost of externality by using the Contingent valuation method (CVM).

\subsection{The aim of the research}

Construction materials mining located in Gowa Regency is one of the biggest revenues and provides employment for the people of Gowa Regency, but behind 
that, there has been an environmental impact due to the mining process, those processes include excavation, production and transportation, and therefore this study aims to (1) determine the environmental impacts caused by construction materials mining (2) identify the valuation of the environment of construction materials mining.

\section{Literature Review}

\subsection{Environmental impact}

The damage to village roads that were passed by trucks carrying sand/gravel/stone because the construction of village roads was not specifically made for trucks loaded with sand, repairs had been made but sometimes later it had suffered the same damage. Trucks that exceed road tonnage further aggravate the damage to village roads [3].

Soil erosion is an important indicator of environmental quality. Erosion is defined as an event of loss or erosion of land or parts of land from a place that is transported from one place to another. Based on the classification of Erosion Hazard Levels according to the Directorate General of Reforestation and Rehabilitation of Forestry Ministry No.041/Kpts/V/1998, the value of TBE obtained is categorized as moderate and mild. This should be taken into consideration and thought because the magnitude of erosion that occurs results in impacts resulting from the high erosion of the local environment and the environment in the lower regions [4].

There is a dependency between land use and water availability. Good land use in the catchment area benefits downstream in the form of water quality, flow regulation, water supply and flow productivity. The high runoff water on the surface of the land causes low water to seep into the soil so that there is a tendency to reduce ground water. The high rate of erosion causes the high water wasted as surface runoff so that groundwater capacity tends to decrease. This is in line with complaints from some residents who claimed that the water in the pond was shrinking [3]. The slope was cut because the land was used for sand excavation, resulting in the cutting of the grooves of the ground so that ground water appeared on the excavated surface. On the excavated land, running water appears and at the bottom forms a kind of pond. The cutting of the soil grooves so that they appear on the surface has an effect on the reduction of groundwater that is underground, resulting in a reduction in water supply elsewhere. The water should be stored as ground water reserves and appear elsewhere [4].

Stone breakers are one of the most vulnerable locations exposed to chemical pollutant factors such as dust, steam and gas. Dust is a solid particulate produced by humans or nature and is the result of the breakdown process. Dust in these locations can cause reduced comfort in the workplace, visual disturbances, even general poisoning. Dust that is inhaled for a long time and continuously can cause lung damage and fibrosis. Dust less than 1 micron meter is very dangerous for the body because it can enter the alveolus [5].

The Government of Indonesia through the Minister of Environment has established environmental noise regulations through the Decree of the Minister of
Environment No. 48/MENLH/11/1996 in 1996 which regulates the noise limits in residential areas or other public facilities. Noise levels in residential areas are set not to exceed $55 \mathrm{dBA}$. Beside that the government has also set a standard noise threshold in the work area according to the Minister of Manpower Decree No. KEP.55/MEN/1999, that the noise threshold value in the work area is a maximum of $85 \mathrm{dBA}$ with an 8 hour exposure time. Noise level values between 55-65 dBALeq affect psychological disorders including personal comfort disorders, communication disorders, psychological disorders such as complaints and demonstration, disturbances in learning concentration, resting disorders, disturbances in prayer/worship activities, sleep disorders and other disorders, while somatic complaints, temporary deafness, and permanent deafnesses are many considered impacts of noise in the work environment /industry [6].

\subsection{Environmental valuation}

One of the methods used in environmental valuation is the Contingent valuation method (CVM). CVM consists of the desire to pay (Willingness to Pay or WTP) and the desire to accept (Willingness to Accept or WTA). WTP is the willingness of a person to make payments for environmental services from an ecosystem that is maintained without pollution and/or partial or total damage or the maximum number of people willing to pay to avoid a decrease in environmental quality or the ability to pay people to obtain goods and services. WTA is the willingness to accept payments for environmental losses that may arise due to pollution and/or damage to an ecosystem or the minimum amount of compensation that someone wants to receive to accept a decrease in environmental quality [7], [8].

In the WTA / WTP method, the respondents will be given questions about willingness to pay to get the value of benefits or the willingness to get compensation for costs for goods and services. Surveys are designed to ask hypothetical questions related to how willing they are to pay or receive compensation to maintain the quality of resources [9].

\section{Research Methodology}

The method used in this study is Willingness to Pay or WTP and Willingness to Accept or WTA through the distribution of WTP questionnaires to construction material mining companies and WTA questionnaires to the people of Gowa Regency who are in the vicinity of construction material mining.

Data collection will be carried out in several ways, as follows:

1) Determine the number of respondents (n) using the random sampling method with Slovin formula:

$$
n=\frac{N}{1+N e^{2}}
$$

where,

$$
\begin{aligned}
& n=\text { number of samples } \\
& N=\text { population Parangloe sub-district (household) } \\
& e \quad=\text { error rate }(10 \%)
\end{aligned}
$$


Table 1. Types and origin of data sources

\begin{tabular}{cll}
\hline No. & \multicolumn{1}{c}{ Type of Data } & \multicolumn{1}{c}{ Data source } \\
\hline & $\begin{array}{l}\text { Material type } \\
\text { Amount of material } \\
\text { production } \\
\text { Material prices }\end{array}$ & $\begin{array}{l}\text { Department of Energy and } \\
\text { Mineral Resources } \\
\text { Mining companies }\end{array}$ \\
& & $\begin{array}{l}\text { Department of Energy and } \\
\text { Mineral Resources }\end{array}$ \\
2. & Bidding variable & $\begin{array}{l}\text { Central Bureau of Statistics } \\
\text { Mining companies } \\
\text { Central Bureau of Statistics of }\end{array}$ \\
& & $\begin{array}{l}\text { Request variable (economic Sulawesi } \\
\text { and infrastructure data) }\end{array}$
\end{tabular}

Table 2. Types and origin of data sources

\begin{tabular}{|c|c|c|c|}
\hline $\begin{array}{c}\text { Respondent } \\
\text { Category }\end{array}$ & $\begin{array}{c}\text { The Way of } \\
\text { Respondents } \\
\text { Selection }\end{array}$ & Type of Data & Method \\
\hline $\begin{array}{l}\text { Community } \\
\text { around the } \\
\text { mining area }\end{array}$ & $\begin{array}{l}\text { Random } \\
\text { Sampling }\end{array}$ & $\begin{array}{c}\text { Socio-cultural } \\
\text { conditions } \\
\text { Public perception } \\
\text { of mining } \\
\text { Large } \\
\text { environmental } \\
\text { costs } \\
\text { who wants to be } \\
\text { accepted }\end{array}$ & $\begin{array}{l}\text { Questionnaire } \\
\text { Interview }\end{array}$ \\
\hline $\begin{array}{c}\text { Mining } \\
\text { companies }\end{array}$ & $\begin{array}{c}\text { PuIDRosive } \\
\text { Sampling }\end{array}$ & $\begin{array}{c}\text { The amount of } \\
\text { environmental } \\
\text { cost that wanted } \\
\text { to be paid } \\
\text { Environmental } \\
\text { impacts caused }\end{array}$ & $\begin{array}{l}\text { Questionnaire } \\
\text { Interview }\end{array}$ \\
\hline
\end{tabular}

2) Observation and survey of mining companies in the Jeneberang River area to find out the type of material produced, the amount of production, market location, and permits owned.

3) Divide the questionnaire to find out the minimum compensation value as an environmental cost which is the value that the company wants to pay (WTP) and which wants to be accepted by the community (WTA).

4) Determine the mean value of the average WTA and WTP as the price balance using the inteIDRolation method with the formula:

$$
M e=\frac{\bar{M}_{w t a}+\bar{M}_{w t p}}{2}
$$

where,

$$
\begin{aligned}
M e & =\text { the median value of the average } \\
& \text { price of WTA and WTP } \\
\bar{M}_{\text {wta }}= & \text { average WTA price } \\
\bar{M}_{\mathrm{wtp}}= & \text { average of WTP price }
\end{aligned}
$$

5) Processing and data analysis:

a. Building a hypothetical market, which is a decrease in environmental quality due to mining activities.

b. Obtain the offer value by using the referendum method, which is by giving a number of price options to the respondents then given the question of agreeing or not.

c. Calculate the frequency number of each bid value chosen by the respondent.

d. Make WTA and WTP graphs from the bid value and number of respondents frequency.

\section{Results and Discussion}

The data collected is the result of the distribution of WTA and WTP questionnaires. The number of respondents from the WTA questionnaire were 99 respondents and WTP as many as 8 respondents. The WTA questionnaire was distributed by random sampling method in the area around construction materials mining and each household was given 1 WTA questionnaire. The WTP questionnaire was distributed using a puIDRosive sampling method with the target of the company being close to residential and public roads. Data from the literature study and questionnaire distribution had been analyzed with the following results:

1) Environmental impacts felt by the local society

a. Erosion

Mining activities carried out along the Jeneberang River cause erosion. Continuous dredging of sand on the riverside causes it to be easily eroded by water currents. This results in widening the river area as happened in Fig. 1.

\section{b. Road damage}

To transport raw construction materials from sand mining along the river, adequate transportation is needed. As a result of sand mining activities, many roads were damaged. This damage is caused by trucks passing every day while the roads made are not designed for everyday trucks crossed. One example of road damage due to sand transport trucks can be seen in Fig. 2.

c. Air pollution and noise

Air pollution produced in sand mining is dust. Dust is generated from rock crusher or crushers. Another source that produces dust is the activity of trucks carrying sand that has been destroyed. When sand is transferred into the truck, dust of sand will carry over and spread to the surrounding air can be seen in Fig. 3. In addition to air pollution, there is also a noise or noise pollution in sand mining activities the main source of noise in the sand mining area is the sound produced from the crusher.

\section{d. Decrease in quality and quantity of clean water}

The sand mining activities carried out on the Jeneberang River have damaged the clean water reserves of the local residents. River water becomes dirty and mixed with mud as shown in Fig. 4. Local residents use the river as the main water source for their daily needs. In addition to the decline in the quality of clean water, due to mining activities, residents have become short of clean water reserves. Dredging of sand causes surface water to emerge.

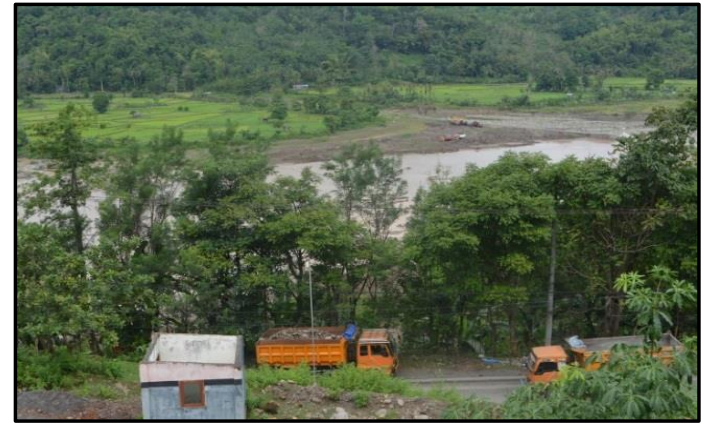

Figure 1. Erosion on the Jeneberang River due to mining activities 




Figure 2. Road damage due to trucks that often pass



Figure 3. Dust of sand from mining activities loaded by sand transport trucks

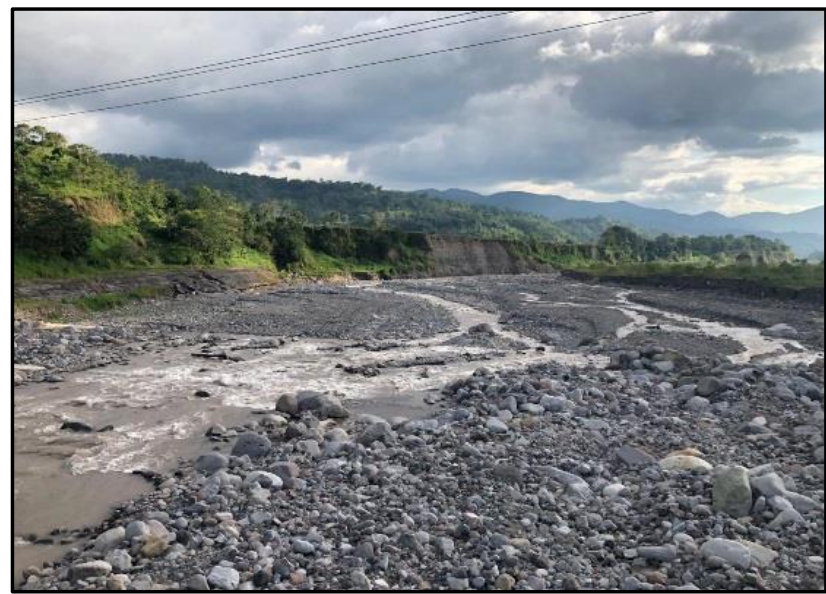

Figure 4. The polluted water of Jeneberang River

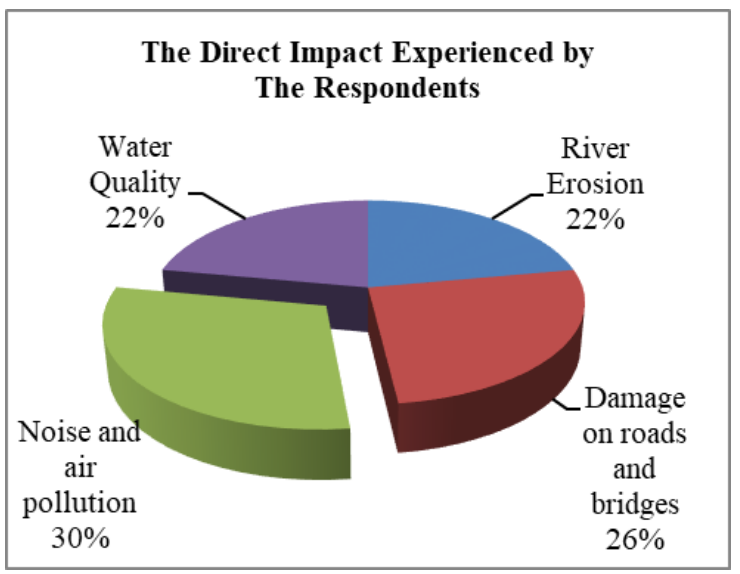

Figure 5. The negative impacts percentage on the environment felt by society
Based on the graph information in Fig. 5, there are 4 environmental impacts caused by the construction material mining in Gowa Regency, based on the questionnaire data have been obtained from the respondents the results show that the noise and air pollution are the dominant environmental impact that felt by the society that is amount of $30 \%$.

e. Environmental valuation

Based on the graph information in Fig. 6, which was made from the results of the WTA questionnaire, the greater the compensation costs offered, the more societies want to receive compensation from the company.

Based on the graph information in Fig. 7, which was made from the WTA questionnaire results, the smaller the compensation costs offered, the more companies want to provide compensation for local societies.

Determine the average price of WTA and WTP and determine the price of balance. The average price of WTA is IDR. 17,303.03 and the average price of WTP is IDR. 13,375.00. Based on the average of WTA and WTP, the balance price obtained is IDR 15,339.02 as summarized in Fig. 8.

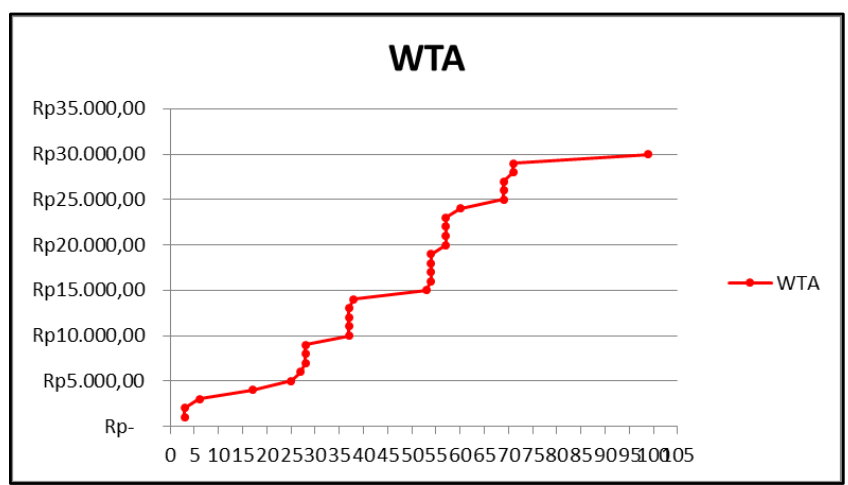

Figure 6. WTA results

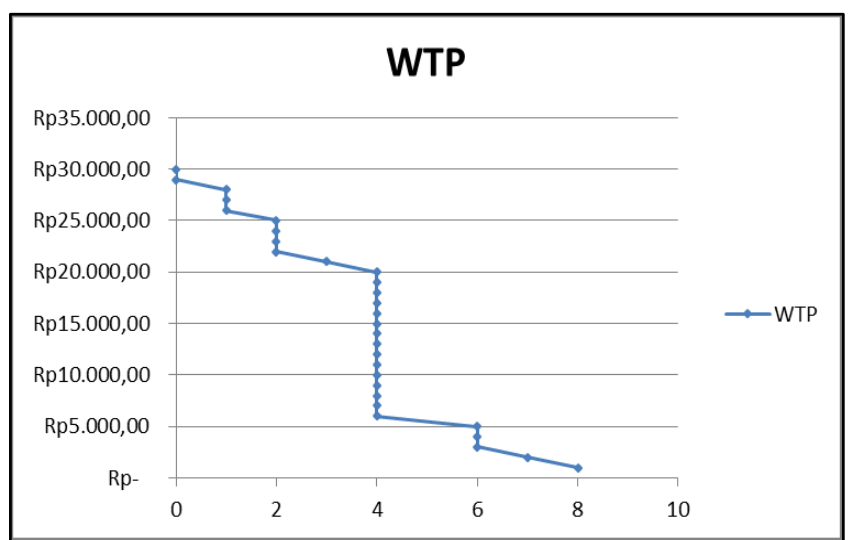

Figure 7. WTP results 


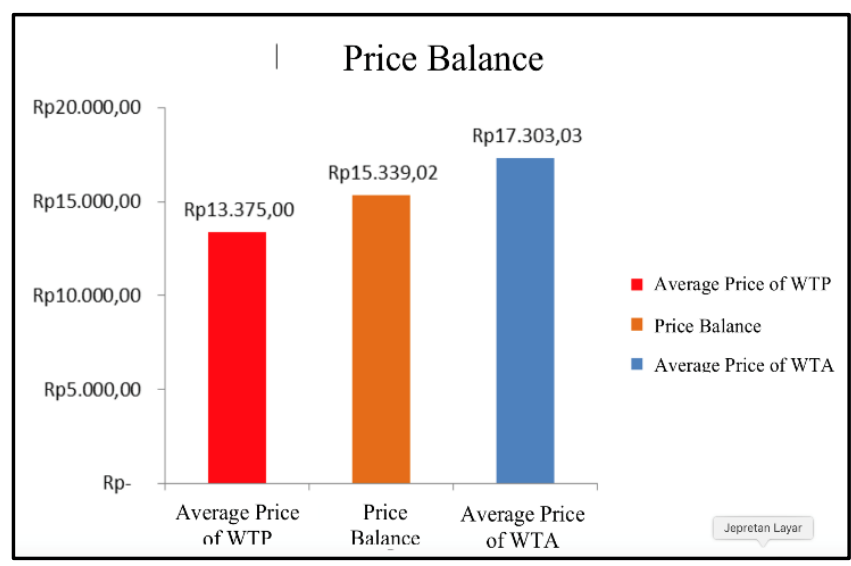

Figure 8. WTA and WTP Price Balance

\section{Conclusions}

Mining of construction materials in Gowa Regency caused environmental impacts such as road damage, river erosion, decrease in water quality and quantity, and pollution of the air and noise, these environmental impacts can occur due to mining of construction materials, mining processes of construction materials which is excavation, production and transportation. Existing environmental impacts can be minimized by the presence of externality costs from environmental valuation, the willingness of the community to accept shows that the greater the compensation costs offered, the more societies want to receive the compensation from the company while the willingness of companies to pay shows the smaller compensation costs offered, the more companies want to provide compensation for local society. The distribution of existing WTP questionnaires shows the average results is IDR. 13,375.00 and the average results of WTA is IDR. 17,303.03, from the results of WTA and WTP, it is then provide a balance price as much as IDR. 15,339.02.

\section{Acknowledgments}

Thanks to the Ministry of Technology and the Higher Education Republic of Indonesia (KEMENRISTEKDIKTI) for providing a forum for Indonesian students to create and work through the Student Creativity Program (PKM), because of this program this research was able to be implemented and completed. Our thanks also go to the people of Gowa Regency who have helped and were willing to provide the information needed, construction material mining companies who were willing to provide the information needed, and to Government of Gowa Regency who has given permission to carry out this research in Gowa Regency.

\section{References}

[1] M. K. Abdurrahman, "Inventarisasi Tumbuhan Pada Ketinggian yang Berbeda Pasca Letusan Gunung Merapi Jalur Pendakian Balerante Kecamatan Kemalang Kabupaten Klaten," Universitas Muhammadiyah Surakarta, 2012.

[2] A. Rifani, "Kajian Kerusakan Lingkungan pada Perairan Sungai Jeneberang Kabupaten Gowa Provinsi Sulawesi Selatan akibat Aktivitas Pertambangan Pasir sebagai Dasar Pengelolaan Lingkungan," Universitas Gadjah Mada., 2017.

[3] I. N. Dyahwanti, "Kajian Dampak Lingkungan Kegiatan Penambangan Pasir pada Daerah Sabuk Hijau Gunung Sumbing di Kabupaten Temanggung," Universitas Diponegoro, 2007.

[4] Yudhistira, W. K. Hidayat, and A. Hadiyarto, "Kajian Dampak Kerusakan Lingkungan akibat Kegiatan Penambangan Pasir di Desa Keningar Daerah Kawasan Gunung Merapi," J. Ilmu Lingkung., vol. 9, no. 2, pp. 76-84, 2011.

[5] K. Ardan, "Hubungan Paparan Debu dan Lama Paparan dengan Gangguan Faal Paru Pekerja Overhaul Power Plant," Indones. J. Occup. Saf. Heal., vol. 4, pp. 155-166, 2015.

[6] S. Hidayat, Purwanto, and G. Hardiman, "Kajian Kebisingan dan Persepsi Ketergangguan Masyarakat akibat Penambangan Batu Andesit di Desa Jeladri, Kecamatan Winongan, Kabupaten Pasuruan Jawa Timur," J. Ilmu Lingkung., vol. 10, no. 2, pp. 95 99, 2012.

[7] A. Fauzi, Ekonomi dan Sumber Daya Alam dan Lingkungan, Teori dan Aplikasi. Jakarta: Gramedia Pustaka Utama, 2004.

[8] Ministry of Environment and Forestry, Ganti Kerugian akibat Pencemaran dan/atau Kerusakan Lingkungan Hidup. Indonesia: Peraturan Menteri Negara Lingkungan Hidup No. 3, 2011.

[9] L. Venkatachalam, "The Contingent Valuation Method: A Review,” Environ. Impact Assess. Rev., no. 24, pp. 89-124, 2004. 